\title{
Modulation of Polyamines during Grain Development under Different Concentrations of Nitrogen in Wheat
}

\author{
B. KAur and B. Asthir* \\ Department of Biochemistry, Punjab Agricultural University, Ludhiana-141004, Punjab, India
}

(Received 25 October 2018; Accepted 16 April 2019)

\begin{abstract}
The polyamine (PAs), putrescine (Put), spermidine (Spd) and spermine (Spm) are small aliphatic amines that ubiquitous in all living organisms. PA metabolism in higher plants is involved in both biotic and abiotic stress responses, and also influenced by nutrient deficiency. Accumulated evidence suggests that in plants the cellular titers of PAs are affected by various nitrogenous compounds. Therefore, the present study analyzed the effects of different nitrogen levels viz. recommended doses of nitrogen (RDN, $120 \mathrm{~kg} \mathrm{~N} / \mathrm{ha}$ ), sub-optimal $\mathrm{N}$ dose (RDN $-25 \%, 90 \mathrm{~kg} \mathrm{~N} / \mathrm{ha}$ ) and supra-optimal $\mathrm{N}$ dose (RDN $+25 \%, 150 \mathrm{~kg} \mathrm{~N} / \mathrm{ha})$ on PA metabolism in grains of six wheat genotypes at 15 days post anthesis (DPA) and 30 DPA. The activities of polyamine synthesizing enzymes (arginine decarboxylase, ornithine decarboxylase), catabolizing (diamine oxidase, polyamine oxidase) and the PA content were increased at supra-optimal nitrogen dose as compared to RDN. Whereas at sub-optimal nitrogen dose, higher activity of polyamine catabolizing enzymes results in speeding up oxidation of various PAs to cope up with nitrogen deficiency in plant. In relation to PA content, Put was found to be higher at early stage whereas Spd and Spm were found to be higher towards mature stages of grain indicating the use of Put in grain filling process. Highly significant correlation was observed between PA metabolism, yield and nitrogen use efficiency at sub-optimal $\mathrm{N}$ dose as compared to supra-optimal dose.
\end{abstract}

Keywords: nitrogen use efficiency, putrescine, spermidine, spermine, wheat, yield

Abbreviations: RDN, recommended doses of nitrogen; DPA, days post anthesis; NUE, nitrogen use efficiency; N, nitrogen; Pas, polyamines; Put, putrescine; Spd, spermidine; Spm, spermine; ODC, ornithine decarboxylase; ADC, arginine decarboxylase; DAO, diamine oxidase; PAO, polyamine oxidase

\section{Introduction}

Nitrogen $(\mathrm{N})$ is among the most important elements in plant nutrition. The intracellular content of various nitrogenous molecules is determined by the uptake of inorganic $\mathrm{N}$ usually in the form of nitrate $\left(\mathrm{NO}_{3}^{-}\right)$and/or ammonium ions $\left(\mathrm{NH}_{4}^{+}\right)$, the assimilation of $\mathrm{NH}_{4}^{+}$, the transport of various $\mathrm{N}$ molecules throughout the plant, and their recycling and remobilization. Assimilation of nitrogen lead to biosynthesis of amino acids, which results in protein synthesis. Besides of these, plant cell also synthesized numerous non-protein

*Corresponding author; E-mail: b.asthir@rediffmail.com; Phone: 919216292388 
amino acids and its derivatives such as ornithine, S-adenosyl-L-methionine (SAM). Ornithine, a member of the urea cycle, and SAM, which is involved in ethylene biosynthesis and provides methyl groups for several trans-methylation reactions, are two important precursors for polyamines (PAs) biosynthesis. The PAs putrescine (Put), spermidine (Spd) and spermine (Spm) are major sinks of assimilated N, due to their high intracellular concentrations (Moschou et al. 2012; Szalai et al. 2017). The nitrogenous groups of PAs along with their carbon (C) scaffold can be efficiently recycled and re-assimilated in various biochemical reactions. The homeostasis of PAs in plants correlates with several important physiological functions, including the control of the $\mathrm{N}$ : C balance (Mattoo et al. 2006; Diao et al. 2017), stress responses (Alcázar et al. 2011), xylem differentiation (Muñiz et al. 2008), pollen tube growth (Wu et al. 2010), membrane fluidity, and protein regulation (Takahashi and Kakehi 2010).

Therefore, PAs, these small biologically active molecules, which are involved in various physiological processes, may play an integral role under different environmental stress conditions. In plants, the diamine Put, is derived either directly from ornithine by ornithine decarboxylase (ODC) or indirectly from arginine, by arginine decarboxylase (ADC) activity (Hanfrey et al. 2001). Spd and Spm are formed by the subsequent addition of an aminopropyl moiety (Xu et al. 2011). On the other hand, diamine oxidase (DAO) and polyamine oxidase (PAO) are thought to play a major role in the catabolism of polyamines in plant tissues. DAO catalyses the oxidative deamination of Put producing $\mathrm{H}_{2} \mathrm{O}_{2}$ and pyrroline while PAO cleaves the aminopropyl side chains at secondary amino group of polyamine substrates, such as Spd and Spm producing $\mathrm{H}_{2} \mathrm{O}_{2}, 1,3$-diaminopropane and 1-pyrroline, respectively (Moschou et al. 2012; Iannone et al. 2013).

Influence of nitrogen nutrition of grapevines on their polyamine metabolism has been investigated by Schaller (2007) and found that a direct influence of N supply on PA synthesis in different tissues could not be proven. While, Altman and Levin (2006) found that the ratio of nitrate to ammonium nutrition affects polyamine biosynthesis and content in intact plants, thus, an increase in Put accumulation was found under conditions of excess ammonium ions, relative to nitrate, and modifications of $\mathrm{N}$ sources in the culture medium of tobacco cell suspensions (depletion of ammonium nitrate, or potassium nitrate, or both) resulted in marked changes in the content of cellular free PAs. Garnica et al. (2009) also published that nitrate supply induces changes in PA content and ethylene production in wheat plants grown with ammonium. They found that both low $(100 \mu \mathrm{M})$ and high $(5 \mathrm{mM})$ nitrate doses caused a rapid and significant increase in free Spd content in roots and shoots, which was well correlated with reduced root ethylene production. In shoots, this increase in free Spd was correlated with changes in the conjugation pattern, while in roots these changes appear to be due to alternative mechanisms. On the other hand, no clear relationship between the supply of a lower dose of nitrate $(100 \mu \mathrm{M})$ and a reduction of free Put content was observed. However, these studies focused only on the PA contents, but not on PA metabolism. The strength of the present MS is the complex investigation mode, as not only the content, but the activities of the synthesis and catabolism enzymes were also measured. 
The present study attempts to reveal relationship between PA metabolism and nitrogen supply in wheat grains. In order to achieve our goal, the activity of enzymes involved in PA synthesis and catabolism along with PA content is paper attempts to associate polyamine metabolism with nitrogen application in wheat. Therefore, the activity of polyamine synthesising and catabolising enzymes alongwith polyamine content were measured at different nitrogen treatments.

\section{Materials and Methods}

\section{Plant material and nitrogen treatments}

Six wheat (Triticum aestivum L.) genotypes viz: PBW 621, PBW 636, PBW 343, PBW 550, HD 2967 and GLU 1356 were raised in the experimental fields of Department of Plant Breeding and Genetics, PAU, Ludhiana. Table 1 summaries the important features of six wheat genotypes used for biochemical analysis at different nitrogen doses. For each wheat variety, three nitrogen treatments were given, namely, recommended doses of nitrogen (RDN, $120 \mathrm{~kg} \mathrm{~N} / \mathrm{ha}$ ), sub-optimal N dose (RDN -25\%, $90 \mathrm{~kg} \mathrm{~N} / \mathrm{ha}$ ) and supraoptimal $\mathrm{N}$ dose $(\mathrm{RDN}+25 \%, 150 \mathrm{~kg} \mathrm{~N} / \mathrm{ha})$. Nitrogen was applied as urea in two equal splits: half at the time of sowing and half at the time of first irrigation. The crop was grown in plots measuring $1 \mathrm{~m} \times 50 \mathrm{~cm}$ in three replications. Each plot consisted of 4 rows with row to row spacing of 9 inches and between the plots was $40 \mathrm{~cm}$. The plots supplied with RDN were taken as controls.

Table 1. Important features of six wheat genotypes used for study nitrogen use efficiency

\begin{tabular}{|l|l|l|}
\hline \multicolumn{1}{|c|}{ Genotype } & \multicolumn{1}{|c|}{ Parentage } & \multicolumn{1}{c|}{ Important features } \\
\hline PBW 621 & $\begin{array}{l}\text { KAUZ//ALTAR84/AOS/3 MILAN/ } \\
\text { KAUZ/4/HUITES }\end{array}$ & $\begin{array}{l}\text { Released variety for timely sown irrigated } \\
\text { conditions }\end{array}$ \\
\hline PBW 636 & KSWW1/PBW 552 & Winter wheat $\times$ Spring wheat derivative \\
\hline PBW 343 & $\begin{array}{l}\text { ND/VG9144//KAL/BB/3/YACO'S'/4/ } \\
\text { Vec\#5 }\end{array}$ & $\begin{array}{l}\text { Widely sown released variety for timely sown } \\
\text { irrigated conditions }\end{array}$ \\
\hline PBW 550 & WH594/RAJ3856//W485 & $\begin{array}{l}\text { Good grain released variety for timely sown } \\
\text { irrigated conditions }\end{array}$ \\
\hline HD 2967 & ALD/COC//URES/3/HD2160M/HD2278 & $\begin{array}{l}\text { Released variety for timely sown irrigated } \\
\text { conditions }\end{array}$ \\
\hline GLU 1356 & GLUPRO/3*PBW554(BWL 0975) & $\begin{array}{l}\text { Lines with high grain protein content conferred } \\
\text { by Gpc-B1 gene originally introgressed from } \\
\text { Triticum dicoccoides } \text { (Tetraploid wild wheat) }\end{array}$ \\
\hline
\end{tabular}




\section{Collection of samples}

Grains were excised at two stages (15 and 30 days post anthesis; 15 DPA and 30 DPA) and used for biochemical analysis. Samples were collected at 9 am daily so as to minimize the effect of diurnal variation.

\section{$D A O$ and PAO extraction and assay}

The leaf samples were extracted in $100 \mathrm{mM}$ potassium-phosphate buffer ( $\mathrm{pH}$ 6.5) containing $5 \mathrm{mM}$ dithiothreitol and the extract was centrifuged at $16,000 \mathrm{~g}$ for $20 \mathrm{~min}$ at $4{ }^{\circ} \mathrm{C}$. The supernatant was used as source of enzyme. DAO and PAO activities were assayed as per Asthir et al. (2002) by using Put (for DAO) and Spd (for PAO) as substrates. The reaction mixture $(2.0 \mathrm{ml})$ consisted of $0.1 \mathrm{ml}$ of enzyme extract, 50 units of CAT, $0.1 \%$ o-aminobenzaldehyde and the reaction started with one of the two different buffer and substrate combinations i.e. $10 \mathrm{mM}$ Put in $50 \mathrm{mM} \mathrm{K}$-phosphate buffer ( $\mathrm{pH}$ 7.5) for DAO; $10 \mathrm{mM}$ Spd in $50 \mathrm{mM}$ K-phosphate buffer ( $\mathrm{pH}$ 6.0) for PAO. The reaction was incubated at $30{ }^{\circ} \mathrm{C}$ for $3 \mathrm{~h}$, and then stopped with $2.0 \mathrm{ml}$ of $10 \%(\mathrm{v} / \mathrm{v})$ perchloric acid and the tubes were centrifuged at $6,500 \mathrm{~g}$ for $15 \mathrm{~min}$. Formation of the D-pyrroline product was determined by reading the absorbance at $430 \mathrm{~nm}$ in spectrophotometer. Control reactions were carried out with inactivated enzyme prepared by heating for $20 \mathrm{~min}$ in a boiling water bath.

\section{Assay of $A D C$ and $O D C$ activities}

The ADC and ODC activities were assayed as described by Birecka et al. (1985) with some modifications. The ADC (ODC) activity was assayed in $1.5 \mathrm{ml}$ of reaction mixture containing $1 \mathrm{ml}$ of assay buffer with $100 \mathrm{mmol} / \mathrm{L}$ Tris-HCl, $\mathrm{pH} 8.5,5 \mathrm{mmol} / \mathrm{L}$ EDTA, $40 \mu \mathrm{mol} / \mathrm{L}$ pyridoxal phosphate and $5 \mathrm{mmol} / \mathrm{L}$ dithiothretol (DTT), $0.3 \mathrm{ml}$ of the ADC enzyme extract and $0.2 \mathrm{ml}$ of $25 \mathrm{mmol} / \mathrm{L} \mathrm{L}$-Arg (or Orn). The reaction mixture was incubated at $37^{\circ} \mathrm{C}$ for $60 \mathrm{~min}$ and centrifugated at $3,000 \mathrm{~g}$ for $10 \mathrm{~min}, 0.5 \mathrm{ml}$ of supernatant was mixed with $1 \mathrm{ml}$ of $2 \mathrm{mmol} / \mathrm{L} \mathrm{NaOH}$, then $10 \mu \mathrm{L}$ of benzoyl chloride was added to the mixture and stirred continuously for $20 \mathrm{sec}$. After conducted at $25^{\circ} \mathrm{C}$ for $60 \mathrm{~min}, 2 \mathrm{ml}$ of saturated $\mathrm{NaCl}$ and $2 \mathrm{ml}$ of ether were added to the reaction mixture stirred thoroughly, then centrifugated at 1,500 $\mathrm{g}$ for $5 \mathrm{~min}, 1 \mathrm{ml}$ of ether phase was collected and evaporated at $50{ }^{\circ} \mathrm{C}$. The remainder was dissolved in $3 \mathrm{ml}$ of methanol, and its absorption value at $254 \mathrm{~nm}$ was measured with a spectrophotometer.

\section{Analysis of polyamines}

The PAs concentrations were measured according to the methods of Dhillon-Grewal et al. (1992). The tissue was homogenized with $5 \%$ cold perchloric acid and the supernatant was collected after centrifugation at $20,000 \mathrm{~g}$ for $30 \mathrm{~min}$ at $4{ }^{\circ} \mathrm{C}$ and transferred to Dowex-50 WX $\mathrm{WX}^{-4}(200-400 \mathrm{mesh})$ columns $(90 \times 4 \mathrm{~mm})$. The columns were washed with 
$40 \mathrm{ml}$ of $0.1 \mathrm{M} \mathrm{Na}$-phosphate buffer $(\mathrm{pH} 8.0$ in $0.7 \mathrm{M} \mathrm{HCl}$ ) followed by $10 \mathrm{ml}$ of $1 \mathrm{~N} \mathrm{HCl}$. The PAs were eluted with increased concentration of $5 \mathrm{ml} \mathrm{HCl}$ : Put $2 \mathrm{M} \mathrm{HCl}$, Spd $3 \mathrm{M}$ $\mathrm{HCl}$ and $\mathrm{Spm} 4 \mathrm{M} \mathrm{HCl}$. After evaporation of elutes to dryness, each sample was dissolved in $0.5 \mathrm{ml}$ of water and portions of $100 \mu \mathrm{l}$ were Put onto filter paper, dried and sprayed with ninhydrin reagent comprising of $1.0 \mathrm{~g}$ ninhydrin, $0.1 \mathrm{~g}$ cadmium acetate, $10 \mathrm{ml}$ water, $5 \mathrm{ml}$ acetic acid and $85 \mathrm{ml}$ acetone. The spots became red after heating at $70{ }^{\circ} \mathrm{C}$ for $60 \mathrm{~min}$. Spots were extracted with $3 \mathrm{ml}$ of solvent consisting of $0.2 \mathrm{~g}$ cadmium acetate, $10 \mathrm{ml}$ water, $40 \mathrm{ml}$ ethanol and $50 \mathrm{ml}$ acetic acid. Extraction was done at room temperature for $30 \mathrm{~min}$ and absorbance was measured at $505 \mathrm{~nm}$. A comparative curve was plotted with the help of standard polyamines passed previously through the Dowex-50 column.

\section{Nitrogen content}

$\mathrm{N}$ content was estimated by the method of McKenzie and Wallace (1954). $10 \mathrm{ml}$ of conc. $\mathrm{H}_{2} \mathrm{SO}_{4}$ and catalyst mixture $\left(8 \mathrm{~g} \mathrm{~K}_{2} \mathrm{SO}_{4}\right.$ and $\left.0.7 \mathrm{~g} \mathrm{CuSO}_{4} \cdot 5 \mathrm{H}_{2} \mathrm{O}\right)$ was added in digestion tubes containing sample and digested the sample at $418{ }^{\circ} \mathrm{C}$ for $20 \mathrm{~min}$ in the Kjeltec digestor. After this, tubes were transferred to the Kjeltec distillation unit and $40 \% \mathrm{NaOH}$ was added which resulted in the production of $\mathrm{NH}_{3}$ which then reacted with boric acid to form ammonium borate. This ammonium borate was titrated with $0.1 \mathrm{~N} \mathrm{HCl}$ till bluish green color changes to pink.

Grain yield was determined by recording the seed yield after threshing. The grain yield of each plot was recorded and expressed as $\mathrm{kg} / \mathrm{sqm}$.

Nitrogen use efficiency (NUE) was calculated by the formula given by Moll et al. (1982):

$$
\text { NUE }=\frac{\text { Grain yield }}{\text { Nitrogen fertilizer application }}
$$

\section{Statistical analysis}

All the values reported in this paper are the mean of three replicates. Data obtained was subjected to split plot design at 5\% level of CD using CPCS1 software developed by Department of Statistics, Punjab Agricultural University, Ludhiana.

\section{Results}

In order to investigate the alteration in PA metabolism under the influence of recommended doses of nitrogen (RDN, $120 \mathrm{~kg} \mathrm{~N} / \mathrm{ha}$ ), sub-optimal $\mathrm{N}$ dose (RDN -25\%, $90 \mathrm{~kg}$ $\mathrm{N} / \mathrm{ha}$ ) and supra-optimal $\mathrm{N}$ dose (RDN $+25 \%, 150 \mathrm{~kg} \mathrm{~N} / \mathrm{ha}$ ), we studied PA synthesizing and catabolizing enzymes along with polyamine content, yield and nitrogen use efficiency (NUE) in grains of six wheat genotypes. Results obtained are presented in Figs 1, 2; Yield and NUE in Table 2 and the correlation between various parameters is given in Table 3. 
Activity of polyamine synthesizing enzymes

The activities of PA synthesizing enzymes viz. arginine decarboxylase (ADC) and ornithine decarboxylase (ODC) decreased from 15 DPA towards 30 DPA (Fig. 1). However, enzyme activity levels showed significant increase with higher dose of $\mathrm{N}$ over RDN. Highest activities of ADC and ODC was observed in GLU 1356 as compared to other genotypes leading to enhanced production of PAs (Put, Spd and Spm).

\section{Activity of polyamine catabolizing enzymes}

The activities of diamine oxidase (DAO) and polyamine oxidase (PAO) progressively increased with increase in $\mathrm{N}$ dose in all genotypes at both 15 and 30 DPA (Fig. 1). Exceptionally at 15 DPA, DAO activity was found more at sub-optimal N dose in GLU 1356, HD 2967, PBW 621 and PBW 636 as compared to RDN indicating that at lower nitrogen dose nitrogen requirement is met by oxidation of various polyamines. Similarly, PAO activity was higher in GLU 1356, HD 2967 and PBW 621 genotypes at sub-optimal N dose. On the other hand, comparison on the basis of stages, DAO and PAO activities decreased towards maturity.

\section{Polyamine content}

Amongst different PAs, Put was found to be maximum during initial stages of grain filling and was in parallel with activity of DAO in all genotypes, however, Spd and Spm

Table 2. Effect of different nitrogen doses on yield ( $\mathrm{kg} / \mathrm{sqm})$ and nitrogen use efficiency (NUE, $\mathrm{kg} \mathrm{kg}^{-1}$ ) of six wheat genotypes

\begin{tabular}{|c|c|c|c|}
\hline \multicolumn{5}{|c|}{ Yield (kg/sqm) } \\
\hline Genotypes & RDN-25\% & RDN\% & RDN+25\% \\
\hline PBW 621 & 0.81 & 1.11 & 1.25 \\
\hline PBW 636 & 0.66 & 0.99 & 1.19 \\
\hline PBW 343 & 0.65 & 0.79 & 0.84 \\
\hline PBW 550 & 0.61 & 0.87 & 1.01 \\
\hline HD 2967 & 0.8 & 1.08 & 1.35 \\
\hline GLU 1356 & 0.81 & 1.11 & 1.16 \\
\hline \multicolumn{2}{|c|}{ NUE $\left(\mathrm{kg} \mathrm{kg}^{-1}\right)$} & 83.1 \\
\hline PBW 621 & 88.5 & 92.2 & 79.1 \\
\hline PBW 636 & 72.9 & 82.8 & 55.8 \\
\hline PBW 343 & 72.5 & 65.8 & 67.1 \\
\hline PBW 550 & 68.1 & 72.2 & 90.2 \\
\hline HD 2967 & 89.3 & 90.1 & 77.6 \\
\hline GLU 1356 & 89.1 & 91.4 & \\
\hline
\end{tabular}


Table 3. Correlation coefficients between biochemical traits, grain yield and NUE at RDN $-25 \%$ in grains (A) $\mathrm{RDN}-25 \%$ and (B) RDN $+25 \%$

\begin{tabular}{|c|c|c|c|c|c|c|c|c|}
\hline \multicolumn{9}{|c|}{$\mathrm{RDN}-25 \%$} \\
\hline & $\mathrm{ADC}$ & ODC & DAO & PAO & Put & Spd & $\mathrm{Spm}$ & Yield \\
\hline ODC & $1.000 * *$ & & & & & & & \\
\hline DAO & 0.976 ** & $0.976^{* *}$ & & & & & & \\
\hline PAO & $0.929 *$ & $0.929 *$ & $0.970^{*}$ & & & & & \\
\hline Put & $0.968^{*}$ & $0.968 *$ & $0.979 * *$ & $0.953^{*}$ & & & & \\
\hline Spd & $0.989 * *$ & $0.989^{* *}$ & $0.986^{* *}$ & $0.963^{*}$ & $0.958^{*}$ & & & \\
\hline Spm & $0.952 *$ & $0.952 *$ & $0.972 * *$ & 0.971 ** & $0.972 * *$ & $0.961 *$ & & \\
\hline Yield & $0.855^{*}$ & $0.855^{*}$ & $0.865^{*}$ & $0.917 *$ & $0.921^{*}$ & $0.858^{*}$ & $0.941^{*}$ & \\
\hline NUE & $0.852 *$ & $0.852 *$ & $0.861^{*}$ & $0.905^{*}$ & $0.927 *$ & $0.848^{*}$ & $0.931 *$ & $0.997 * *$ \\
\hline \multicolumn{9}{|c|}{$\mathrm{RDN}+25 \%$} \\
\hline ODC & $1.000 * *$ & & & & & & & \\
\hline DAO & $0.975 * *$ & $0.975^{* *}$ & & & & & & \\
\hline PAO & $0.897 *$ & $0.897 *$ & $0.964 *$ & & & & & \\
\hline Put & $0.973 * *$ & $0.972 * *$ & $0.993^{* *}$ & $0.961 *$ & & & & \\
\hline Spd & $0.978 * *$ & $0.977 * *$ & $0.997 * *$ & $0.956^{*}$ & $0.984 * *$ & & & \\
\hline Spm & $0.916^{*}$ & $0.917 *$ & $0.967^{*}$ & $0.941^{*}$ & $0.977 * *$ & $0.947 *$ & & \\
\hline Yield & 0.745 & 0.749 & 0.768 & 0.844* & 0.785 & 0.773 & 0.725 & \\
\hline NUE & 0.756 & 0.756 & 0.777 & $0.849^{*}$ & 0.794 & 0.782 & 0.734 & $1.000^{* *}$ \\
\hline
\end{tabular}

*** Significantly different at $5 \%$ and $1 \%$ level, respectively.

content were maximum towards grain maturity which indicate that Put act as precursor for the synthesis of higher polyamines (Fig. 2). Irrespective of the stage of grain development, PA content was recorded highest in GLU 1356 and lowest in PBW 343.

\section{Nitrogen content}

Nitrogen content was high at the beginning of anthesis then decreased towards 30 DPA in wheat grains (Fig. 2). In relation to genotypes, $\mathrm{N}$ content was found maximum in GLU 1356 followed by HD 2967, PBW 621, PBW 636, PBW 343, PBW 550. In all treatments, it was in accordance with increasing amount of nitrogen and the order was $\mathrm{RDN}+25 \%>\mathrm{RDN}>\mathrm{RDN}-25 \%$. These results indicated that higher $\mathrm{N}$ level (supraoptimal dose) results in increase in $\mathrm{N}$ content which speed up the PAs biosynthesis.

Significant increase in grain yield was observed in crop supplied with higher dose of $\mathrm{N}$ as observed in our study (Table 2). In general, GLU 1356, HD 2967 found to be tolerant genotype showing higher nitrogen uptake and its utilization, whereas PBW 621, PBW 636 as mild tolerant, and PBW 343, PBW 621 as susceptible genotypes showing least nitrogen use efficiency. 


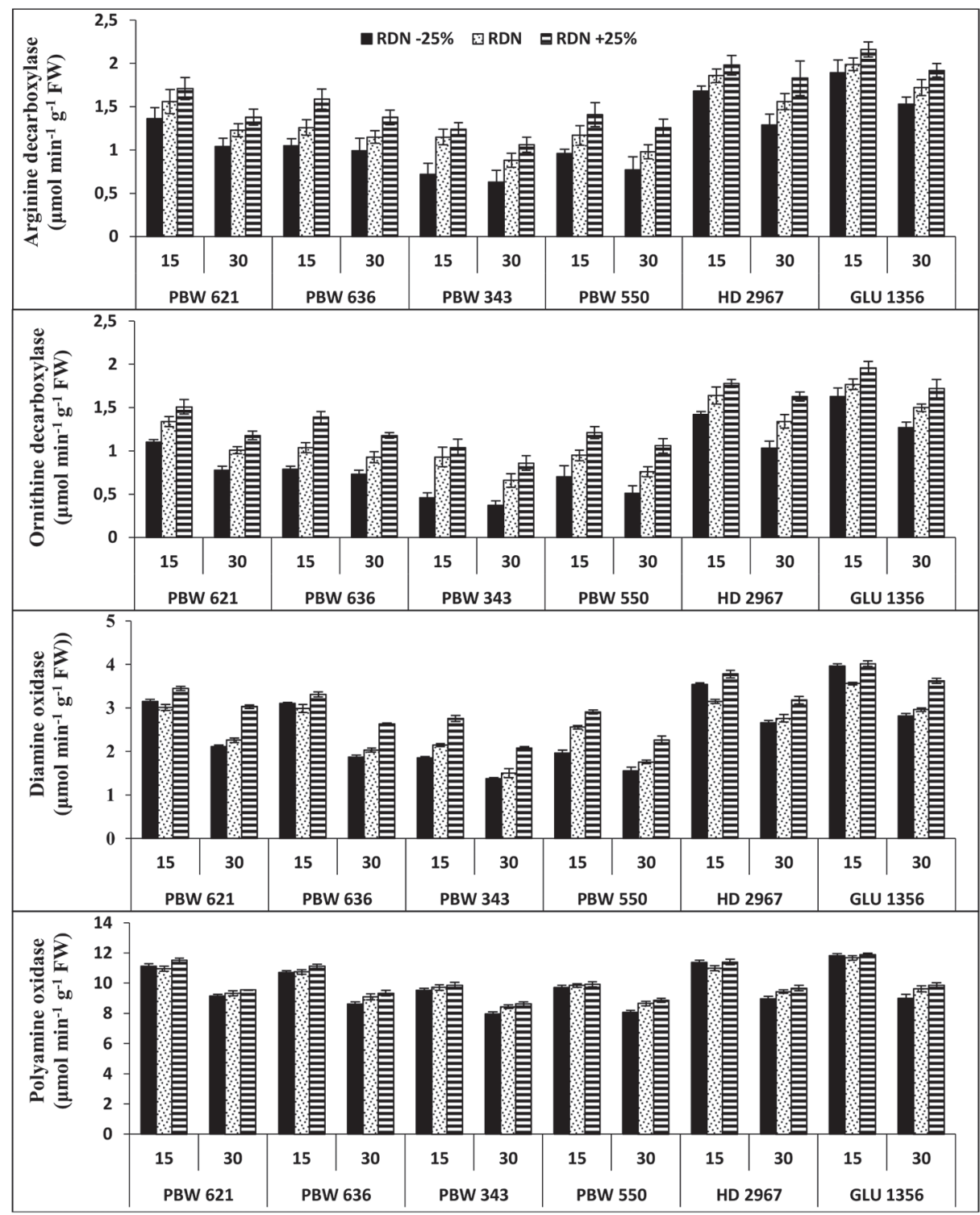

Figure 1. Effect of different doses of nitrogen on polyamine synthesizing enzymes (ADC, ODC) and catabolizing enzymes (DAO, PAO) in grains at 15 and 30 days post anthesis (DPA) of six wheat genotypes. ADC (A-0.99, B-1.73, C-1.09), ODC (A-0.72, B-1.83, C-1.46), DAO (A-1.22, B-1.56, C-1.73), PAO (A-1.42, $\mathrm{B}-1.60, \mathrm{C}-1.05$ ) where $\mathrm{A}$ is genotypes, $\mathrm{B}$ is treatments and $\mathrm{C}$ is stages. The values of $\mathrm{A}, \mathrm{B}$ and $\mathrm{C}$ are the critical differences at $5 \%$ level of significance while vertical bars on graph represent standard errors 


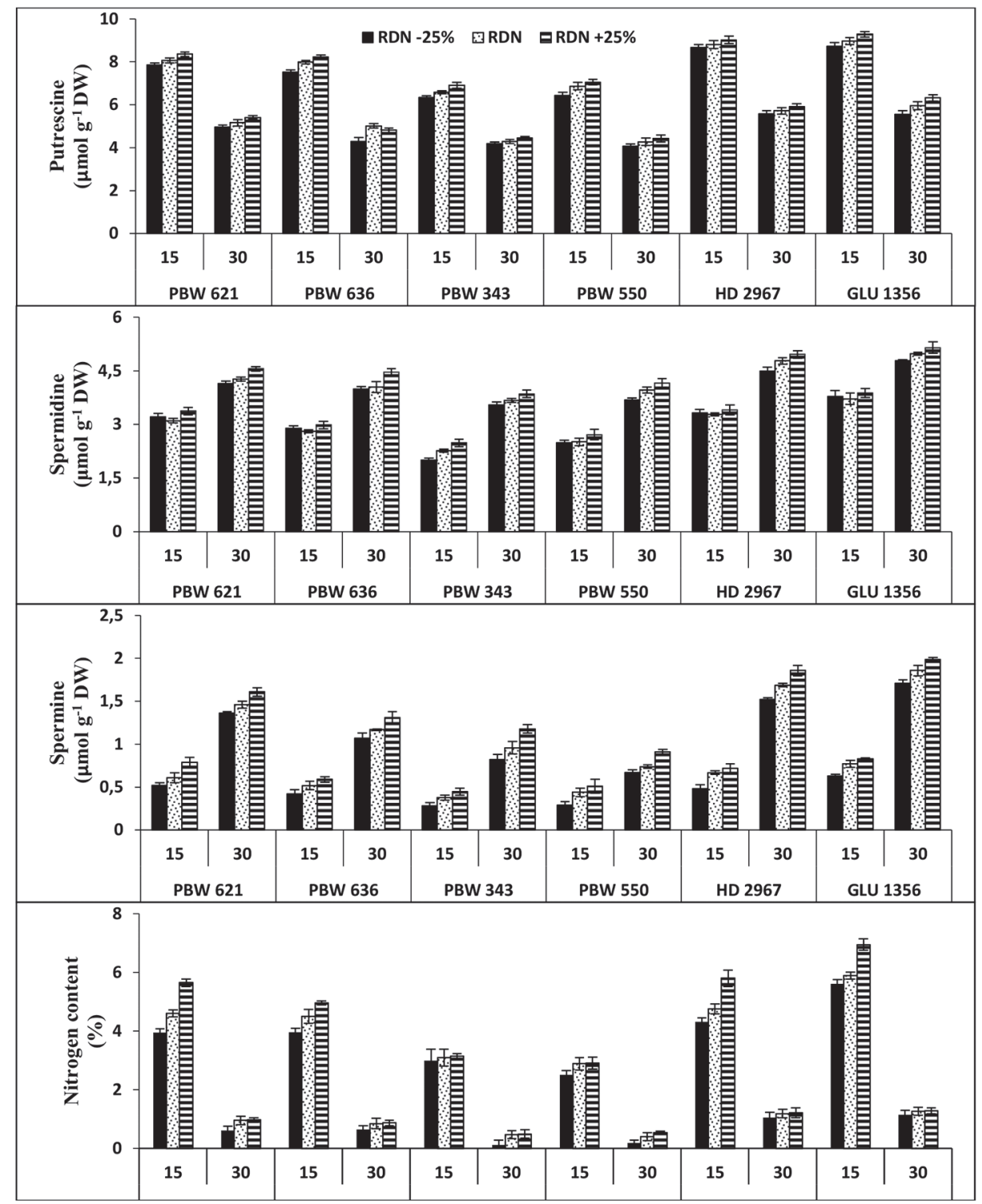

Figure 2. Effect of different doses of nitrogen on polyamine content (putrescine, spermidine, spermine) and nitrogen content in grains at 15 and 30 days post anthesis (DPA) of six wheat genotypes. Put (A-0.99, B-1.17, C-1.35), Spd (A-1.17, B-1.44, C-1.38), Spm (A-1.67, B-1.44, C-1.38), N (A-0.036, B-0.035, C-0.043) where $\mathrm{A}$ is genotypes, $\mathrm{B}$ is treatments and $\mathrm{C}$ is stages. The values of $\mathrm{A}, \mathrm{B}$ and $\mathrm{C}$ are the critical differences at $5 \%$ level of significance while vertical bars on graph represent standard errors 
Correlation analysis between polyamines metabolizing enzymes and polyamine content with respect to yield and NUE evaluated at grain developmental stages is shown in Table 3 at sub-optimal, supra-optimal $\mathrm{N}$ dose and recommended dose of nitrogen.

\section{Discussion}

It has been well documented that higher activities of ADC and ODC results in higher levels of PAs, which could confer plant tolerance to abiotic stress by acting as direct ROS scavengers or binding to antioxidant enzyme molecules to scavenge free radicals (Groppa and Benavides 2008). On the other hand, $\mathrm{N}$ flow towards PAs may serve as a strategy of cells to (re)store $\mathrm{N}$ or alternatively PAs could act as sinks for excess $\mathrm{NH}_{4}^{+}$, thereby reducing its toxicity in plant cell by speeding up its utilization in other nitrogen products (Primikirios and Roubelakis-Angelakis 2001; Skopelitis et al. 2006; Serapiglia et al. 2008).

The variation in PAO and DAO activities with respect to PAs content can be supported by the fact that the bulk of PAs and their catabolic enzymes do not co-exist in the same subcellular compartment under physiological conditions (Rea et al. 2004), under stress conditions and perhaps during different developmental stages, PAs and their catabolic enzymes come in contact, as shown in tobacco plants (Moschou et al. 2008). These results suggest that high content of Put at initial stage of grain filling is due to active biosynthetic machinery of PAs synthesis. Similar to our observations, Feng et al. (2011) also reported that higher levels of Spd and Spm were closely associated with higher kernel set and better seed development in maize and greater grain filling rate in rice (Yang et al. 2008). Yield-related parameters have also reported to be in a significant positive relationship with the PA contents of durum wheat flag leaves (Bányai et al. 2017).

To characterize the role of PAs in the plant growth under nitrogen deficiency, we determined the levels of PAs in grains at sub- and supra-optimal nitrogen doses. Low level of Put was observed at sub-optimal $\mathrm{N}$ dose as compared to RDN. Nitrogen-deficient condition had much lower level of Put than RDN. Altman and Levin (1993) also demonstrated decreased in PA content in tobacco cells under nitrogen deficiency. Interestingly, GLU 1356, HD 2967, PBW 621 and PBW 636 showed high Spd and Spm content at suboptimal $\mathrm{N}$ dose indicating that higher activity of catabolic enzymes results in more polyamine degradation, which act as $\mathrm{N}$ source for plant metabolism and development at $\mathrm{N}$ deficient conditions as compared to PBW 343 and PBW 550 (Pfosser et al. 1992; Geny and Broquedis 2002). Therefore, these results suggested the role of PA content in abiotic stress tolerance mechanism (Groppa and Benavides 2008; Lowe-Power et al. 2018).

The increase in polyamine content was reported at supra-optimal dose of $\mathrm{N}$ as compared to RDN and Sub-optimal dose (Primikirios et al. 2000). This increase in PAs at higher nitrogen dose concluded that higher $\mathrm{N}$ uptake, its assimilation and metabolism act as direct precursors of PAs biosynthesis and regulation (Szalai et al. 2017). Mohapatra et al. (2010) also reported the interconnection between PAs and N pools. However, Kato et al. (2003) reported that plants grown under high-intensity light with a high $\mathrm{N}$ supply had greater tolerance to photo-oxidative damage and higher photosynthesis capacity than those grown under similar high light with a low $\mathrm{N}$ supply. Utilization of the absorbed light 
energy in electron transport was also much higher in N-adequate than in N-deficient plants. These results indicate that $\mathrm{N}$-adequate plants are able to tolerate excess light by maintaining photosynthesis at high rates and developing protective mechanisms through the action of polyamines.

Significant increase in grain yield was observed in crop supplied with higher dose of $\mathrm{N}$ as observed in our study (Table 2) and also reported by Singh et al. (2000) and Sial et al. (2005). A decrease in NUE with increasing fertilizer rates is due to less increase in grain yield in comparison to N supply (Table 2) as observed by Lopez-Bellido and LopezBellido (2001) in wheat.

At sub-optimal $\mathrm{N}$ dose, highly significant correlation was found between PAs synthesizing, catabolizing, PA content, yield and NUE as compared to supra-optimal N dose. On the other hand, at supra-optimal N dose, ADC, ODC, DAO, Put, Spd and Spm non-significantly correlated with yield and NUE. However, at RDN, only Put was non-significantly correlated with Spm, yield and NUE. Therefore, it can be concluded that at RDN and lower nitrogen dose activates the PA synthesis as well as oxidation to meet the nitrogen deficiency requirements for better plant growth and development, which shows PA content to have a role in abiotic stress tolerance.

\section{References}

Alcázar, R., Cuevas, J.C., Planas, J., Zarza, X., Bortolotti, C., Carrasco, P., Salinas, J., Tiburcio, A.F., Altabella, T. 2011. Integration of polyamines in the cold acclimation response. Plant Sci. 180:31-38.

Altman, A., Levin, N. 2006. Interaction of polyamines and nitrogen nutrition in plants. Physiol. Plant 89:653658.

Asthir, B., Duffus, C.M., Smith, R.C., Spoor, W. 2002. Diamine oxidase is involved in $\mathrm{H}_{2} \mathrm{O}_{2}$ production in the chalazal cells during barley grain filling. J. Exp. Bot. 53:677-682.

Bányai, J., Maccaferri, M., Cané, M.A., Monostori, I., Spitkó, T., Kuti, C., Mészáros, K., Láng, L., Pál, M., Karsai, I. 2017. Phenotypical and physiological study of near-isogenic durum wheat lines under contrasting water regimes. South African J. Bot. 108:248-255.

Birecka, H., Bitonti, A.J., McCann, P.P. 1985. Assaying ornithine and arginine decarboxylase in some plant species. Plant Physiol. 79:509-514.

Dhillon-Grewal, R., Virk, D.S., Mangat, B.K., Basra, R.K., Basra, A.S. 1992. Polyamine levels in anthers of poly-cytoplasmic isonuclear male sterile lines of pearl millet. Bot. Bull. Academia Sinica 33:97-100.

Diao, Q., Song, Y., Shi, D., Qi, H. 2017. Interaction of polyamines, abscisic acid, nitric oxide, and hydrogen peroxide under chilling stress in tomato (Lycopersicon esculentum Mill.) seedlings. Front. Plant Sci. 8:203.

Feng, H.Y., Wang, Z.M., Kong, F.N., Zhang, M.J., Zhou, S.L. 2011. Roles of carbohydrate supply and ethylene, polyamines in maize kernel set. J. Integr. Plant Biol. 53:388-398.

Garnicaa, M., Houdussea, F., Claude, Yvinc., Garcia-Mina, J.M. 2009. Nitrate supply induces changes in polyamine content and ethylene production in wheat plants grown with ammonium content and ethylene production in wheat plants grown with ammonium J. Plant Physiol. 166:363-374.

Geny, L., Broquedis, M. 2002. Developmental processes, polyamine composition and content of fruiting cuttings of Vitis vinifera L.: Responses to nitrogen deficiency. Vitis 41:123-127.

Groppa, M.D., Benavides, P.M. 2008. Polyamines and abiotic stress: recent advance. Amino Acids 34:35-45.

Hanfrey, C., Sommer, S., Mayer, M.J., Burtin, D., Michael, A.J. 2001. Arabidopsis polyamine biosynthesis: absence of ornithine decarboxylase and the mechanism of arginine decarboxylase activity. Plant J. 27:551560 . 
Iannone, M.F., Rosales, E.P., Groppa, M.D., Benavides, M.P. 2013. $\mathrm{H}_{2} \mathrm{O}_{2}$ Involvement in polyamine-induced cell death in tobacco leaf discs. J. Plant Growth Regul. 4:745-757.

Kato, M.C., Hikosaka, K., Hirotsu, N., Makin, A., Hirose, T. 2003. The excess light energy that is neither utilized in photosynthesis nor dissipated by photoprotective mechanisms determines the rate of photoinactivation in photosystem II. Plant Cell Physiol. 44:318-325.

Lopez-Bellido, R.J., Lopez-Bellido, L. 2001. Efficiency of nitrogen in wheat under Mediterranean condition: effect of tillage, crop rotation and $\mathrm{N}$ fertilization. Field Crop Res. 71:31-64.

Lowe-Power, T.M., Hendrich, C.G., von Roepenack-Lahaye, E., Li, B., Wu, D., Mitra, R., Dalsing, B.L., Ricca, P., Naidoo, J., Cook, D., Jancewicz, A., Masson, P., Thomma, B., Lahaye, T., Michael, A. J., Allen, C. 2018. Metabolomics of tomato xylem sap during bacterial wilt reveals Ralstonia solanacearum produces abundant putrescine, a metabolite that accelerates wilt disease. Environ. Microbiol. 20:1330-1349.

Mattoo, A.K., Sobolev, A.P., Neelam, A., Goyal, R.K., Handa, A.K., Segre, A.L. 2006. Nuclear magnetic resonance spectroscopy-based metabolite profiling of transgenic tomato fruit engineered to accumulate spermidine and spermine reveals enhanced anabolic and nitrogen-carbon interactions. Plant Physiol. 142:17591770 .

McKenzie, H.A., Wallace, H.S. 1954. The Kjeldahl determination of nitrogen. Aust. J. Chem. 17:55-59.

Mohapatra, S., Minocha, R., Long, S., Minocha, S. 2010. Transgenic manipulation of a single polyamine in poplar cells affects the accumulation of all amino acids. Amino Acids 38:1117-1129.

Moll, R.H., Kamprath, E.J., Jackson, W.A. 1982. Analysis and interpretation of factors which contribute to efficiency of nitrogen utilization. Agron. J. 74:562-564.

Moschou, P.N., Paschalidis, K.A., Roubelakis-Angelakis, K.A. 2008. Plant polyamine catabolism: the state of the art. Plant Signal. Behav. 3:1061-1066.

Moschou, P.N., Wu, J., Cona, A., Tavladoraki, P., Angelini, R., Roubelakis-Angelakis, K.A. 2012. The polyamines and their catabolic products are significant players in the turnover of nitrogenous molecules in plants. J. Exp. Bot. 63:5003-5015.

Muñiz, L., Minguet, E.G., Singh, S.K., Pesquet, E., Vera-Sirera, F., Moreau-Courtois, C.L., Carbonell, J., Blázquez, M.A., Tuominen, H. 2008. ACAULIS5 controls Arabidopsis xylem specification through the prevention of premature cell death. Development 135:2573-2582.

Pfosser, M., Mengel, M., Konigshofer, H., Kandeler, R. 1992. Time course pf polyamine levels during starvation of Medicago Varia cells and its correlation with cell cycle data. J. Plant Physiol. 140:334-338.

Primikirios, N.I., Roubelakis-Angelakis, K.A. 2001. Indications for post-translational regulation of Vitis vinifera L. arginine decarboxylase. Plant Mol. Biol. 45:669-678.

Primikirios, N.I., Loulakakis, K.A., Lefort, F., Roubelakis-Angelakis, K.A. 2000. Nitrogen metabolism and recycling genes cloned from Vitis vinifera L. Acta Hortic. 528:231-239.

Rea, G., De Pinto, M.C., Tavazza, R., Biondi, S., Gobbi, V., Ferrante, P., De Gara, L., Federico, R., Angelini, R., Tavladoraki, P. 2004. Ectopic expression of maize polyamine oxidase and pea copper amine oxidase in the cell wall of tobacco plants. Plant Physiol. 134:1414-1426.

Schaller, K. 2007. Influence of nitrogen nutrition of grapevines on their polyamine metabolism. Acta Hortic. 64:7-12.

Serapiglia, M.J., Minocha, R., Minocha, C.S. 2008. Changes in polyamines, inorganic ions and glutamine synthetase activity in response to nitrogen availability and form in red spruce (Picea rubens). Tree Physiol. 28:1793-1803.

Sial, M.A., Arain, M.A., Naqvi, S.K.M.H., Dahot, U., Nizamani, N.A. 2005. Yield and quality parameters of wheat genotypes as affected by sowing dates and high temperature stress. Pak. J. Bot. 37:575-584.

Singh, M.K., Thakur, R., Verma, U.N., Upasani, R.R., Pal, S.K. 2000. Effect of planting time and nitrogen on production potential of Basmati rice cultivars in Bhiar Plateau. Indian J. Agron. 45:300-303.

Skopelitis, D.S., Paranychianakis, N.V., Paschalidis, K.A., Pliakonis, E.D., Delis, I.D., Yakoumakis, D.I., Kouvarakis, A., Papadakis, A.K., Stephanou, E.G., Roubelakis-Angelakis, K.A. 2006. Abiotic stress generates ROS that signal expression of anionic glutamate dehydrogenases to form glutamate for proline synthesis in tobacco and grapevine. Plant Cell 18:2767-2781.

Szalai, G. et al. 2017 Comparative analysis of polyamine metabolism in wheat and maize plants. Plant Physiol. Biochem. 112:239-250. 
Takahashi, T., Kakehi, J. 2010. Polyamines: ubiquitous polycations with unique roles in growth and stress responses. Ann. Bot. 105:1-6.

Wu, J., Shang, Z., Jiang, X., Moschou, P.N., Sun, W., Roubelakis-Angelakis, K.A., Zhang, S. 2010. Spermidine oxidase-derived $\mathrm{H}_{2} \mathrm{O}_{2}$ regulates pollen plasma membrane hyperpolarization-activated $\mathrm{Ca}^{2+}$-permeable channels and pollen tube growth. Plant J. 63:1042-1053.

Xu, X., Shi, G., Ding, C., Xu, Y., Zhao, J., Yang, H., Pan, Q. 2011. Regulation of exogenous spermidine on the reactive oxygen species level and polyamine metabolism in Alternanthera philoxeroides (Mart.) Griseb under copper stress. Plant Growth Regul. 63:251-258.

Yang, J.C., Cao, Y., Zhang, J.H., Liu, L., Zhang, J. 2008. Involvement of polyamines in the post-anthesis development of inferior and superior spikelets in rice. Planta 228:137-149. 